DOI: $10.2478 / \mathrm{v} 10025-008-0010-5$

JOURNAL OF WATER

AND LAND DEVELOPMENT

J. Water Land Dev. No. 11, 2007: 117-130

\title{
Comparative analysis of the geotechnical properties of coal mining wastes from Lublin Coal Basin and from other basins
}

\author{
Piotr FILIPOWICZ, Magdalena BORYS
}

Institute for Land Reclamation and Grassland Farming at Falenty, Department of Land Reclamation Engineering, Hrabska 3, 05-090 Raszyn, Poland; p.filipowicz@imuz.edu.pl,m.borys@imuz.edu.pl

\begin{abstract}
There are 40 coal mines in Poland now. One of them (coal mine "Bogdanka") is situated in Lublin Coal Basin, other are localised in Silesia and Małopolska regions. Coal mining is a source of large amounts of wastes. Mean annual production of wastes in only Lublin Coal Basin exceeds 2 million $\mathrm{Mg}, 65 \%$ of which is disposed on a heap. The rest is used to restore opencast excavations, to construct and repair local roads and to produce building materials. It seems that large amount of these wastes could be used to construct or modernize flood embankments and dykes. Using mine wastes as building materials requires the knowledge of their geotechnical parameters. A characteristic feature of mine wastes is their gradual weathering which affects geotechnical parameters largely determined by their mineral and petrographic composition.

This paper describes analyses of geotechnical parameters of mine wastes from Lublin Coal Basin (heap near coal mine "Bogdanka") of various storage times and of samples collected after 10 years of exploitation of a dyke between ponds made of these wastes at the break of 1993 and 1994. Detailed analyses involved: grain size distribution, natural and optimum moisture content, maximum dry density, shear strength and coefficient of permeability. Obtained results were compared with literature data pertaining to mine wastes from Upper Silesian Coal Basin and from other European coal basins.

Performed studies showed that coal mining wastes produced in Lublin Coal Basin significantly differed in the grain size distribution from wastes originating from Upper Silesian Coal Basin and that weathering proceeded in a different way in wastes produced in both sites.
\end{abstract}

Key words: coal mining wastes, grain size distribution, ground embankments, mechanical properties, shear strength

\section{INTRODUCTION}

There are 40 coal mines in Poland now. One of them is situated in Lublin Coal Basin, other are localised in Silesia and Małopolska regions.

Coal mining is a source of large amounts of wastes. Mean annual production of wastes in only Lublin Coal Basin exceeds 2 million $\mathrm{Mg}, 65 \%$ of which is dis- 
posed on a heap near coal mine Bogdanka. The rest is used to restore opencast excavations, to construct and repair local roads and to produce building materials. It seems that large amount of these wastes could be used to construct or modernize flood embankments and dykes. Using mine wastes as building materials requires the knowledge of their geotechnical parameters.

Studies on these parameters referred mainly to wastes from Silesian coal mines (GRUCHOT, 2001; KOZIELSKA-SROKA, 1995; PIECZYRAK, 2004; SKARŻYŃSKA, 1997; SKARŻYŃSKA and BURDA, 1988; SKARŻYŃSKA et al., 1987). These wastes were first used in hydro-engineering in the seventies of the XX century.

Coal deposits were found in the Lublin region not earlier than in the middle of the sixties and coal mine Bogdanka was constructed in the beginning of the eighties of the XX century. Therefore, studies on wastes from that particular coal mine, due to its much shorter existence, are modest and less frequently presented in publications (see e.g. BORYS et al., 2002; BORYS and FILIPOWICZ, 2004a, b, 2005; FILIPOWICZ, 2006).

A characteristic feature of mine wastes is their gradual weathering which affects geotechnical parameters largely determined by their mineral and petrographic composition.

Literature data on petrographic composition of mine wastes indicate that the latter are mainly composed of claystone and siltstone (Badania..., 2000; CEBULAK and KOZŁOWSKI, 1980; GAZDA et al., 1988; SKARŻYŃSKA, 1997). The content of claystone in wastes from Upper Silesian Coal Basin reaches up to $98 \%$ while in Spain its contribution is $70 \%$ and in Germany - up to $66 \%$. Claystones are impermanent; easily undergo decomposition which alters geotechnical parameters of mine wastes. Siltstones in mine wastes have an aleurite massive and compact texture which is rarely layered. They are pale grey or grey. Siltstones are characterised by good mechanical properties and insolubility in water. Other rocks present in mine wastes are sandstones, carbonaceous shales and sporadically conglomerates of coal crumbs (SKARŻYŃSKA, 1997).

Mineral composition of mine wastes is closely related to petrographic composition of the parent rock. Main minerals present in mine wastes are clay minerals (over 50\%) and quartz (over 30\%). The remaining 20\% consists of other minerals and coal (SKARŻYŃSKA, 1997). Claystones are mainly of kaolinite-illite or kaolinite-sericite type. They are accompanied by quartz, carbonates, pyrite and coal (TWARDOWSKA, 1981). The content of illite in mine wastes does not exceed $60 \%$ in Spain and Germany and 30\% in Great Britain. The content of quartz does not exceed $60 \%$ in Spain, 30\% in Germany and 40\% in Poland (SKARŻYŃSKA, 1997).

Coal beds in Lublin Coal Basin are composed of Westphalian deposits having 300 to 310 million years of age (Upper Carboniferous). They are covered by grounds and rocks 360 to over $1000 \mathrm{~m}$ thick. Coal beds and accompanying rocks exploited now are situated at a depth of c. $920 \mathrm{~m}$. 
Petrographic composition of coal mine wastes from Lublin Coal Basin are given in Table 1 and compared with respective data from Upper Silesian Coal Basin. According to collected data from last years relate to petrographic composition, wastes from both sources are dominated by claystones of various types. Wastes from Lublin Coal Basin contain, however, much less claystones, sandstones, carbonate rocks and coal than in wastes from USCB. Wastes from both basins contain similar amounts of siltstones.

Table 1. Petrographic composition of mine wastes from Lublin Coal Basin (LCB) and Upper Silesian Coal Basin (USCB)

\begin{tabular}{|c|c|c|c|c|c|}
\hline \multirow{3}{*}{ Rock } & \multicolumn{5}{|c|}{ Content, $\%$} \\
\hline & \multicolumn{4}{|c|}{ LCB } & USCB \\
\hline & $1980^{1)}$ & $1981^{2)}$ & $1984^{3)}$ & $2000^{4)}$ & $1997-2003^{5)}$ \\
\hline Claystones & 67 & $31.3-65.2$ & 60 & 70 & $73-98$ \\
\hline Siltstones & 11 & $34.2-46.7$ & 20 & 20 & $2-40$ \\
\hline Sandstones & 9 & $16-18$ & 15 & traces & $2-33$ \\
\hline $\begin{array}{l}\text { Carbonate rocks (siderite, } \\
\text { marl, limestone) }\end{array}$ & 13 & $6-8.4$ & 5 & 10 & $1-25$ \\
\hline
\end{tabular}

1) Cebulak, KozŁowski (1980), ${ }^{2)}$ Stochlak, SzcZerbiński $(1981),{ }^{3)}$ Surowce... (1984), ${ }^{4)}$ Badania... (2000), ${ }^{5)}$ SKARŻYŃSKA (1997), KRZYK (2003).

Main minerals (Table 2) in mine wastes from Lublin Coal Basin are clay minerals and quartz with admixtures of siderite, feldspar, pyrite, calcite and organic substances. No trends were found of changes of the given mineral composition with time which is evidenced by results of studies carried out in the eighties and nineties of the XX century. Clay minerals dominate also in mine wastes from Upper Silesian Coal Basin. Their content together with organic substances is similar to that found in wastes from Lublin Coal Basin. In spite of similar content of clay minerals, wastes from Lublin Coal Basin contain more minerals like kaolinite and illite but definitely less mixed montmorillonite-illite layers. Wastes from Lublin Coal Basin contain less organic substances than those from Upper Silesia. To sum up, mine wastes from Lublin Coal Basin are of kaolinite-illite type with a large content of quartz while those from Upper Silesian Coal Basin are of montmorillonite-illite type with a large amount of organic substances.

Thus it appears that petrographic and mineral composition of wastes from Lublin and Upper Silesian Coal Basins differ between each other which may affect geotechnical parameters of these wastes.

This paper describes analyses of geotechnical parameters of samples of coal mine wastes from Lublin Coal Basin (heap near coal mine "Bogdanka") of various storage times and collected after 10 years of exploitation of a dyke between ponds made of these wastes at the turn of 1993 and 1994. Detailed analyses involved: 
Table 2. Mineral composition of mine wastes

\begin{tabular}{|c|c|c|c|}
\hline \multirow{3}{*}{ Components } & \multicolumn{3}{|c|}{ Content, \% } \\
\hline & \multicolumn{2}{|c|}{ LCB } & USCB \\
\hline & $1986-1987^{1)}$ & $1998-2000^{2)}$ & $2003^{3)}$ \\
\hline Clay minerals & $61-68$ & $60-65$ & $43-54$ \\
\hline Kaolinite & $29-30$ & $30-35$ & $17-20$ \\
\hline Illite & $23-29$ & $20-25$ & $10-15$ \\
\hline Chlorite & $6-7$ & $5-10$ & 5 \\
\hline Montmorillonite & $2-3$ & traces-10 & $3-22^{4)}$ \\
\hline Quartz & $15-23$ & $20-25$ & $10-13$ \\
\hline Mica & $3-5$ & traces & - \\
\hline Feldspar & traces -1 & traces -5 & $5-10$ \\
\hline Syderite & $2-5$ & $2-5$ & 2 \\
\hline Calcite & - & traces & - \\
\hline Pyrite & traces & traces & 2 \\
\hline Dolomite & traces -0.5 & - & $2-5$ \\
\hline Organic substances (carbon) & $7-9$ & $5-10$ & $20-30$ \\
\hline
\end{tabular}

grain size distribution, natural and optimum moisture content, maximum dry density, shear strength and coefficient of permeability. Obtained results were compared with literature data pertaining to coal mine wastes from Upper Silesian Coal Basin and from other European coal basins.

\section{MATERIALS AND METHODS}

Wastes from current production taken directly from the conveyor belts transporting them onto heap near Bogdanka coal mine and wastes stored there for 5 and 7 years were used in this study. Analyses of samples taken from a dyke made of fresh mine wastes transported directly from the coal mine at the turn of 1993 and 1994 were used for comparative purposes. Cross section of the dyke is shown in Figure 1.

Basic physical parameters of sampled wastes were determined first. These parameters included: grain size distribution, natural and optimum moisture content and maximum dry density.

Grain size distribution was estimated by sieving after preliminary soaking waste samples. This procedure was performed to unstick clay and silt particles from larger particles. Pre-weighed waste sample of a mass of $5 \mathrm{~kg}$ was soaked in water for several hours and then washed with running water through a sieve of a mesh size of $0.063 \mathrm{~mm}$. Washed samples were dried at a temperature of $105 \pm 5^{\circ} \mathrm{C}$ 


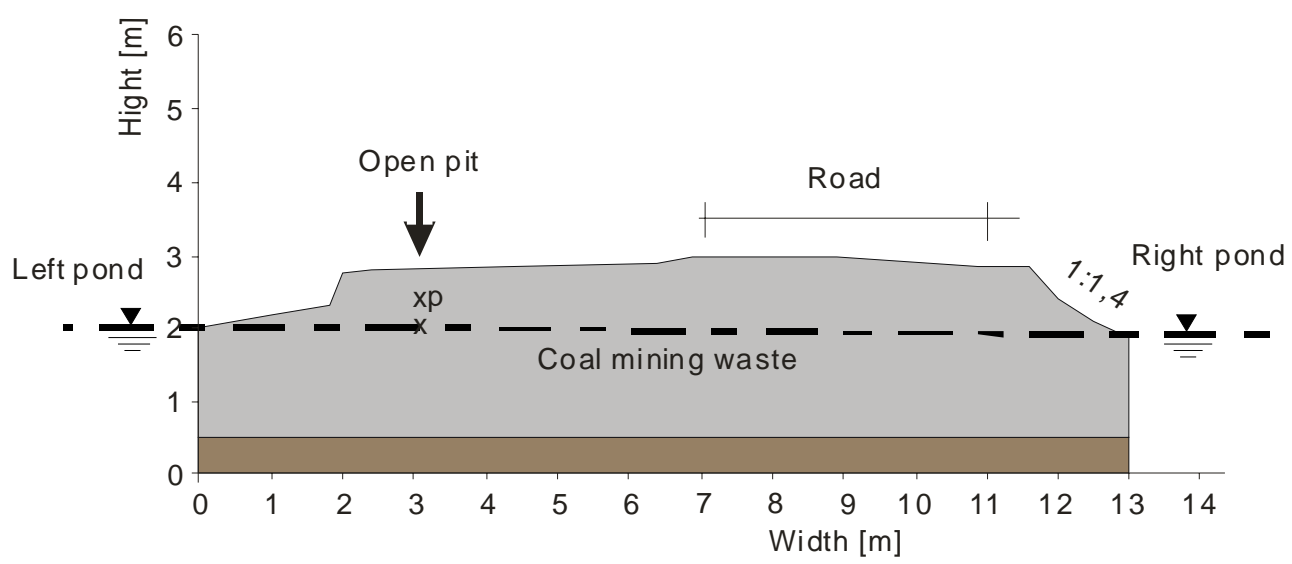

Fig. 1. Cross-section of the dyke: $x$ - sampling site of large samples for detailed lab studies, $p$ - sampling site to determine dry density of built-in coal mine wastes (FILIPOWICZ and BORYS, 2006)

for at least $24 \mathrm{~h}$. So prepared samples were sieved in a shaker through square sieves of mesh sizes $40.0 \mathrm{~mm}, 25.0 \mathrm{~mm}, 10.0 \mathrm{~mm}, 2.0 \mathrm{~mm}, 1.0 \mathrm{~mm}, 0.5 \mathrm{~mm}, 0.25 \mathrm{~mm}$, $0.1 \mathrm{~mm}$ and $0.063 \mathrm{~mm}$. Based on masses obtained from particular sieves (and those outwashed previously) the content of particular fractions was calculated and grain size distribution curve was drawn.

Because the content of particles larger than $40 \mathrm{~mm}$ was small (mean 5\%) it was decided that compactibility and strength parameters of wastes could be determined without preliminary segregation.

Compactibility of studied coal mine wastes was analysed in the Proctor apparatus with the II method acc. to PN-88/B-04481. Analyses were made in samples with complete grain size distribution except for several samples from which single grains larger than $40 \mathrm{~mm}$ were removed. All tested samples were characterised with ratio of the diameter of the apparatus cylinder (D) to the diameter of maximum grain in the sample $\left(d_{\max }\right)$ about 5 . To eliminate the effect of crushing the grains during compaction, analyses were always made with new samples of wastes.

Mechanical properties i.e. cohesion and apparent angle of internal friction of coal mine wastes were analysed with large triaxial apparatus and direct shear apparatus.

Fresh wastes and those stored for 7 years on a heap were analysed for shear strength in a large triaxial apparatus in the laboratory of Geoengineering Department of the Warsaw University of Agriculture. Analyses were made with the UU method i.e. without consolidation and outflow during shear at a constant stress $\sigma_{3}$ of 50,100 and $150 \mathrm{kPa}$. Samples had complete grain size distribution. Moisture content of wastes was adjusted close to the optimum one and then such mass was weighed to form single sample of a compaction index equal 0.92. Weighed material was compacted in layers $50 \mathrm{~mm}$ thick each in a special cylinder of a diameter 
of $250 \mathrm{~mm}$ and height of $500 \mathrm{~mm}$ with a pestle from manual Proctor apparatus of a mass of $4.1 \mathrm{~kg}$ which was dropped form a height of $320 \mathrm{~mm}$ which corresponded to the compaction energy equal to $0.59 \mathrm{~J} \cdot \mathrm{cm}^{-3}$. So prepared sample was ready for analyses performed with a constant deformation rate of $25 \mathrm{~mm} \cdot \mathrm{h}^{-1}$. All tested samples were characterised with ratio of the diameter of the apparatus cylinder (D) to the diameter of maximum grain in the sample $\left(d_{\max }\right)$ over 6.

Apparatus for direct shear measurements used for analyses was equipped with a box $120 \times 120 \times 60 \mathrm{~mm}$. Single grains, if present, were removed from analysed samples. All tested samples were characterised with ratio of the diameter of the apparatus cylinder (D) to the diameter of maximum grain in the sample $\left(d_{\max }\right)$ about 5. Samples of coal mine wastes were adjusted to optimum moisture and then compacted in the box by pounding in 3 layers so as to obtain the compaction index of $\mathrm{c}$. 0.92 . Shear was performed at a rate of $0.1 \mathrm{~mm} \mathrm{~min}^{-1}$ using standard stress $\sigma$ of 15 , $30,45,60,75$ and $90 \mathrm{kPa}$. Every next stress was applied to a separately prepared sample.

Coefficient of permeability was determined in the lab in filtration cylinders for samples $15 \mathrm{~cm}$ high and $13.9 \mathrm{~cm}$ in diameter. The ratio of the diameter of filtration cylinder (D) to the diameter of maximum grain in the sample $\left(d_{\max }\right)$ was about 5. Before measurements the moisture content of analysed samples was adjusted to the value close to optimum. Then, the samples were compacted in filtration cylinders to obtain the compaction index of $I_{s} \geq 0.92$. Coefficient of permeability was determined by directing water flow from top to bottom of the sample.

\section{RESULTS AND DISCUSSION}

Grain size distribution of coal mining wastes from Lublin Coal Basin is presented in Table 3 and compared with respective data for wastes from Upper Silesian Coal Basin.

Performed analysis demonstrated a clear effect of storage time on the grain size distribution in coal mining wastes from Lublin Coal Basin. The older wastes the less large particles they contained. Gravel was the largest fraction in all samples. Its share ranged from $70-75 \%$ in fresh wastes, from 58 to $74 \%$ in the 5 years old samples and from 45 to $67 \%$ in the 7 years old samples. Contribution of the gravel fraction (and cobble) decreased with storage time (by $30 \%$ maximum after 7 years). Cobble fraction in old wastes was represented by single grains and particles larger than $40 \mathrm{~mm}$ were not present in over half of the 5 and 7 years old samples. The wastes were characterised by a high content of very small particles. The percentage share of silt and clay fractions in fresh wastes may reach $20 \%$ and in older samples it may even exceed 30\%. In samples collected from 10 years old dyke the percentage share of particular size fractions was similar to that of fresh wastes. 
Table 3. Grain size distribution of coal mining wastes from mines in Lublin Coal Basin (LCB) and Upper Silesian Coal Basin (USCB) data acc. to SKARŻYŃSKA (1997)

\begin{tabular}{l|c|c|c|c}
\hline \multirow{2}{*}{ Wastes } & \multicolumn{4}{c}{ Content of the fraction, \% } \\
\cline { 2 - 5 } & $\begin{array}{c}\text { cobbles } \\
>40 \mathrm{~mm}\end{array}$ & $\begin{array}{c}\text { gravel } \\
2-40 \mathrm{~mm}\end{array}$ & $\begin{array}{c}\text { sand } \\
0.063-2 \mathrm{~mm}\end{array}$ & $\begin{array}{c}\text { silt and clay } \\
<0.063 \mathrm{~mm}\end{array}$ \\
\hline $\begin{array}{l}\text { LCB Coal Mine Bogdanka } \\
- \text { fresh }\end{array}$ & $0-12$ & $70-75$ & $6-10$ & $8-19$ \\
- -5-years old & $0-5$ & $58-74$ & $13-23$ & $12-19$ \\
-7 -years old & $0-8$ & $45-67$ & $14-19$ & $19-34$ \\
-10 -years old dyke & $0-13$ & $70-80$ & $6-12$ & $8-21$ \\
USCB from dumping sites & & & & \\
- new & $30-38$ & $43-54$ & $10-15$ & $3-8$ \\
- old & $4-18$ & $38-61$ & $9-21$ & $2-30$ \\
\hline
\end{tabular}

Coal mining wastes from Upper Silesian Coal Basin contained more large particles and less small fractions than those from Lublin Coal Basin (Table 3).

Grain size distribution in fresh wastes was similar to that of wastes built in 10 years old dyke (Fig. 2). One should, however, notice that fresh material originated from the years 2001 and 2002 while the dyke was made of then fresh wastes in 1993. Therefore, results of such comparison should be treated cautiously.

Figure 2 shows also the range of grain sizes in fresh wastes from Upper Silesian Coal Basin and grain size curve for wastes built in 2 years old embankment. Remarkable difference of their grain size structure after 2 years of natural weathering in the embankment is clearly visible. Performed comparison allows for the conclusion that wastes from Upper Silesian Coal Basin are more susceptible to environmental conditions than wastes from Lublin Coal Basin.

Changes in the grain size distribution proceeding under the effect of weathering observed in mine wastes from Lublin Coal Basin are similar to respective trends in wastes from Upper Silesian Coal Basin in Poland and in wastes from Ruhr and Saar Basins in Germany (CISEK et al., 1982, SKARŻYŃSKA, 1997). According to these authors, very long storage time of wastes may cause the decrease of gravel and cobble fraction to the benefit of particles from clay and silt fractions which means that the wastes acquire the features typical for cohesion soils.

Observed alteration of the grain size distribution of mine wastes due to weathering results in changes of other geotechnical parameters. Compatibility parameters of studied wastes showed a distinct decline in maximum dry density and an increase of optimum moisture content with the storage time on a heap (Table 4).

SKARŻYŃSKA (1997) observed similar increase of optimum moisture content from $7-12 \%$ in fresh wastes to $11-19 \%$ in old material for mine wastes from USCB. Maximum dry density ranged from 1.7 to $1.9 \mathrm{Mg} \cdot \mathrm{m}^{-3}$ in fresh wastes and from 1.2 to $2.0 \mathrm{Mg} \cdot \mathrm{m}^{-3}$ in old wastes. 


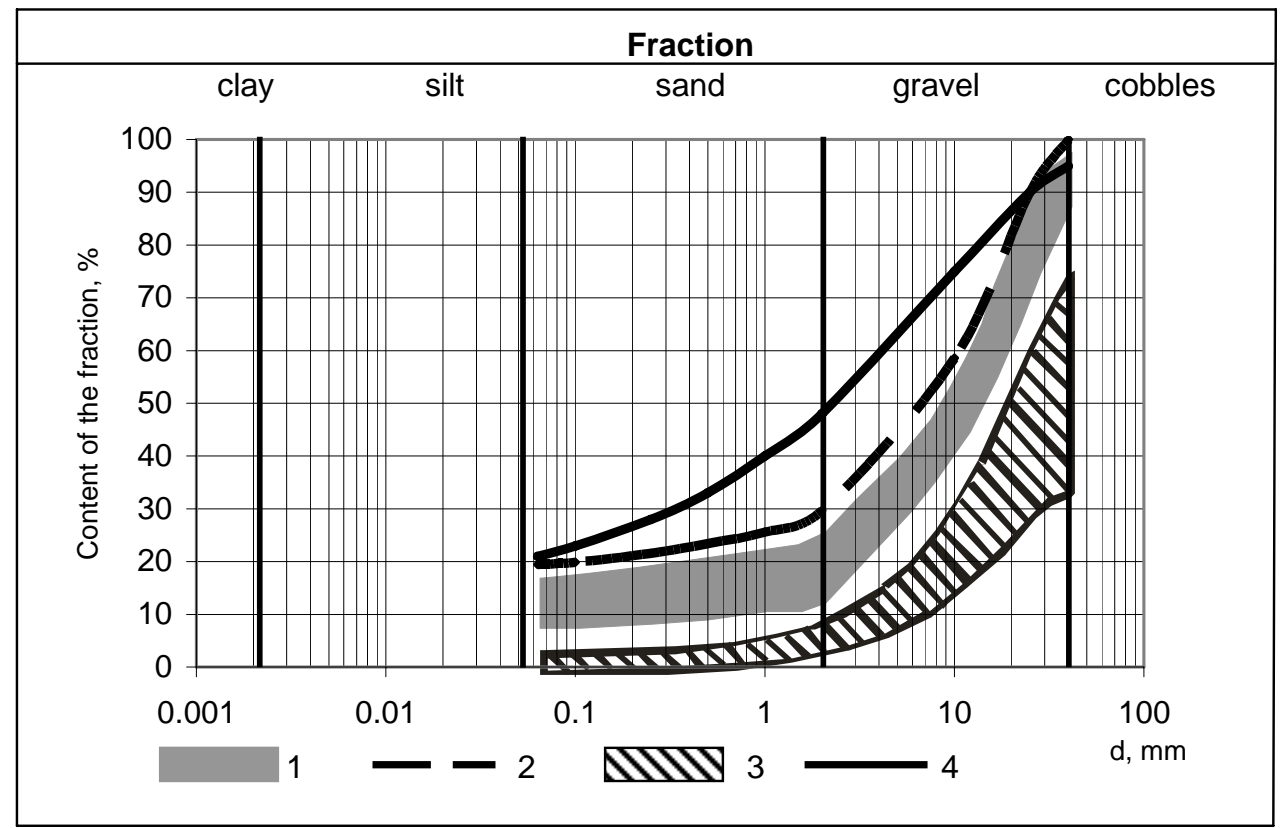

Fig. 2. Grain size distribution of coal mining wastes: 1 - fresh from Lublin Coal Basin, 2 - from a dyke after 10 years of natural weathering, 3 - fresh from Upper Silesian Coal Basin (SKARŻYŃSKA, 1997), 4 - fresh from Upper Silesian Coal Basin after 2 years of natural weathering in an embankment (SKARŻYŃSKA et al., 1987)

Table 4. Compatibility parameters of mine wastes from coal mines of Lublin Coal Basin (LCB) and Upper Silesian Coal Basin (USCB)

\begin{tabular}{l|c|c|c|c|c}
\hline \multirow{2}{*}{ Parameter } & \multicolumn{3}{c|}{ Wastes from LCB } & \multicolumn{2}{c}{$\begin{array}{c}\text { Wastes from USCB } \\
\text { (SKARŻYŃSKA, 1997) }\end{array}$} \\
\cline { 2 - 6 } & fresh & 5-years old & 7-years old & fresh & old \\
\hline$\rho_{d \max }, \mathrm{Mg} \cdot \mathrm{m}^{-3}$ & $1.790-1.950$ & $1.690-1.751$ & $1.640-1.710$ & $1.700-1.900$ & $1.200-2.000$ \\
$w_{\text {opt }}, \%$ & $11.0-13.0$ & $11.0-14.0$ & $15.0-19.0$ & $7.0-12.0$ & $8.0-19.0$ \\
$w_{n}, \%$ & $9.4-13.0$ & $9.7-11.0$ & $12.5-14.8$ & $4.0-10.0$ & $5.0-19.0$ \\
\hline
\end{tabular}

Explanations: $\rho_{d \max }-$ maximum dry density of solid particles, $w_{\mathrm{opt}}-$ optimum moisture, $w_{n}-$ natural moisture.

Shear strength of studied wastes from Lublin Coal Basin is presented in Table 5.

Our results obtained with triaxial apparatus were compared with analyses made in the same way but using wastes from heaps in Great Britain (Rainbow 1987 after SKARŻYŃSKA, 1997). Results are presented in Figure 3 as a relationship between the apparent angle of internal friction and cohesion. This comparison showed that our results were similar to data from British studies. 
Table 5. Shear strength of mining wastes from Lublin Coal Basin in relation to different storage time

\begin{tabular}{l|c|c|c|c|c|c|c|c}
\hline \multirow{2}{*}{ Apparatus } & \multicolumn{3}{|c|}{ Apparent angle of internal friction, } & \multicolumn{4}{c}{ Cohesion, kPa } \\
\cline { 2 - 8 } & fresh & $\begin{array}{c}5 \text {-year } \\
\text { old }\end{array}$ & $\begin{array}{c}7 \text {-year } \\
\text { old }\end{array}$ & $\begin{array}{c}10 \text {-year old } \\
\text { embankment }\end{array}$ & fresh & $\begin{array}{c}5 \text {-year } \\
\text { old }\end{array}$ & $\begin{array}{c}7 \text {-year } \\
\text { old }\end{array}$ & $\begin{array}{c}10 \text {-year old } \\
\text { embank- } \\
\text { ment }\end{array}$ \\
\hline $\begin{array}{l}\text { Large triaxial } \\
\text { apparatus }\end{array}$ & 29 & - & 27 & - & 48 & - & 57 & - \\
$\begin{array}{l}\text { Direct shear } \\
\text { apparatus }\end{array}$ & $43-55$ & $34-35$ & $27-39$ & $31-50$ & $22-32$ & $21-35$ & $25-40$ & $20-51$ \\
\hline
\end{tabular}

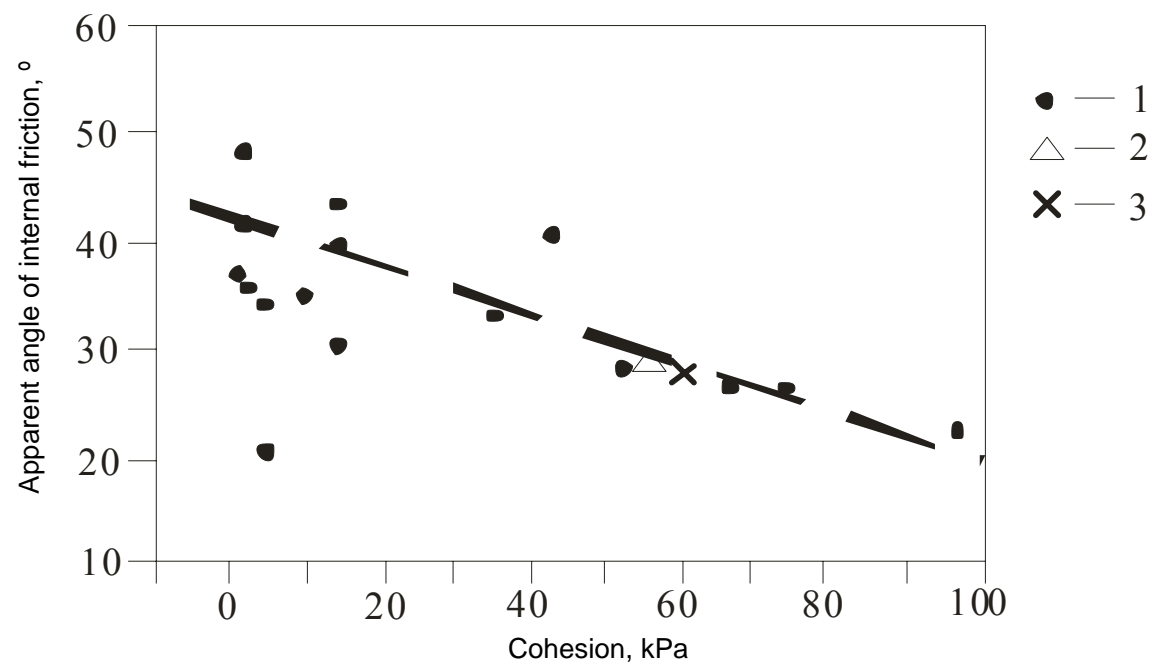

Fig. 3. Comparison of apparent angle of internal friction and cohesion of coal mining wastes determined with a large triaxial apparatus: 1 - from dumping sites in Great Britain (Rainbow 1987 after

SKARŻYŃSKA, 1997), 2 - fresh from Lublin Coal Basin, 3 - 7 years old from Lublin Coal Basin

Values of apparent angle of internal friction and cohesion obtained from two instruments indicate that the sample size is important in determining mechanical parameters of mine wastes. Results obtained with large triaxial apparatus seem to be more reliable. Results from direct shear apparatus are burdened with large measurement error but show the relationships between changes in the grain size distribution and the storage period.

Results obtained from the direct shear apparatus confirmed that the advancement of weathering is accompanied by increased value of apparent angle of internal friction and by decreased cohesion. Apparent angle of internal friction in fresh 
wastes ranged from about $43^{\circ}$ to $55^{\circ}$ while in 7 -years old wastes - from about $27^{\circ}$ to $39^{\circ}$.

Apparent angle of internal friction estimated with large triaxial apparatus was smaller than the mean value determined in the direct shear apparatus by c. $14^{\circ}$ for fresh wastes and by c. $5^{\circ}$ for wastes stored on a heap for 7 years. Cohesion measured with the former apparatus was greater by c. $24 \mathrm{kPa}$ in fresh wastes and by c. $26 \mathrm{kPa}$ in 7-years old wastes than that determined with the latter instrument. Observed changes in stress parameters were due to the disintegration of larger particles into smaller ones. Large particles of sharp edges tend to wedge which results in great values of apparent angle of internal friction. In old wastes such particles are rare; therefore we observe smaller values of the angle. Greater cohesion in old than in fresh mine wastes is an effect of a large content of silt and clay fractions.

Changes of the stress parameters in wastes from Lublin Coal Basin are similar to those presented in the literature for mine wastes from Upper Silesian Coal Basin. Depending on the storage time apparent angle of internal friction in wastes from USCB may decrease even by $20^{\circ}$ and differences in cohesion between fresh and old wastes may reach $50 \mathrm{kPa}$ or more (KAWALEC, 1976; KRZYK, 2001; SKARŻYŃSKA, 1997).

Analyses of permeability showed that the mean coefficient of permeability in samples of fresh wastes from Lublin Coal Basin were of the order of $10^{-4} \mathrm{~m} \cdot \mathrm{s}^{-1}$, in 5 -years old samples $-10^{-6} \mathrm{~m} \cdot \mathrm{s}^{-1}$, and in 7-years old $-10^{-7} \mathrm{~m} \cdot \mathrm{s}^{-1}$. Generally, all studied coal mining wastes were characterised by a coefficient of permeability adequate for middle permeable soil.

Samples of wastes taken from the dyke between ponds had coefficient of permeability in the range between $10^{-8}$ and $10^{-5} \mathrm{~m} \cdot \mathrm{s}^{-1}$. Only in cross section 1 the coefficient was greater $\left(k=3.37 \cdot 10^{-3} \mathrm{~m} \cdot \mathrm{s}^{-1}\right)$ due to poor compaction ( $I s=0.70$ to 0.82) of coal mining wastes in this section of the dyke's body. After compacting these wastes in the lab to $I s=0.92$, coefficient of permeability decreased to $k=4.84 \cdot 10^{-5} \mathrm{~m} \cdot \mathrm{s}^{-1}$.

Performed analyses demonstrated that coefficient of permeability in coal mining wastes depended on the storage time in a heap. In samples taken from the dyke's body the coefficient depended also on compaction of wastes built in the dyke. Decreased permeability of older wastes is associated with disintegration of large particles. Samples containing many large particles of the gravel and cobble fractions are more permeable. Older wastes containing more fine particles than the fresh ones show lower permeability.

\section{CONCLUSIONS}

1. Performed analyses showed that mine wastes from Lublin Coal Basin differ significantly in the grain size distribution from wastes originating from Upper Sile- 
sian Coal Basin. This structure in fresh wastes from LCB was similar to loamy gravel with cobble fraction of $0-$ several percent and a significant content of sandy, silt and clay fractions (several to 25 percent in total). Wastes from USCB containing $25-66 \%$ of cobble fraction, $30-62 \%$ gravel fraction and small percentage of fine particles can be classified as stony rubble of negligible content of sandy, silt and clay fractions.

2. Grain size distribution largely depends on the way of exploitation of coal deposits, on technology of coal processing and on mineral and petrographic composition. All mine wastes are known to be subject to weathering but different mineral and petrographic composition makes this process runs with varying rate. Consequently it affects the rate of disintegration of particles from particular size classes. It is particularly visible in studying wastes stored in heaps. With the advancement of storage we observed the decrease in the content of cobble and gravel fractions and increasing share of fine particles from sandy, silt and clay fractions. Weathering rate differed between wastes from LCB and USCB. Grain size structure of 5-years old wastes from Lublin Coal Basin was similar to that of 3-15 years old wastes from Upper Silesian Coal Basin. Contribution of silt, clay and sandy fractions in the latter was markedly greater than in 7-years old wastes from Lublin Coal Basin.

3. Changes of their geotechnical parameters result from the changes in the grain size distribution. Optimum and natural moisture content of analysed wastes from Lublin Coal Basin tended to increase with the time of storage in a heap. These parameters were higher for wastes from LCB than from USCB. Maximum dry density, however, decreased with time but difference in this parameter between wastes from the two compared coal basins was small.

4. Disintegration of large particles into fine fractions markedly affects stress parameters of wastes. Apparent angle of internal friction decreases and cohesion increases with the time of storage in a heap. Our measurements of these parameters made with large triaxial apparatus were similar to data obtained for wastes from heaps in Great Britain. Changes in stress parameters of wastes from Lublin Coal Basin are similar to those given in the literature for wastes from Upper Silesian Coal Mine. Depending on the storage time the angle of internal friction in Silesian wastes may decrease by even $20^{\circ}$ and cohesion of fresh and old wastes may differ by $50 \mathrm{kPa}$ or more.

5. Changes in the grain size distribution of analysed coal mining wastes during storage resulted in decreased coefficient of permeability. Our results demonstrate that this parameter decreased from $10^{-4} \mathrm{~m} \cdot \mathrm{s}^{-1}$ in fresh wastes to $10^{-5} \mathrm{~m} \cdot \mathrm{s}^{-1}$ in 5 years old samples to $10^{-6} \mathrm{~m} \cdot \mathrm{s}^{-1}$ in 7 -years old samples.

6. Observed tendency of decreasing coefficient of permeability with time in wastes from LCB is similar to that noted in the literature. Mine wastes from Upper 
Silesian Coal Basin had the coefficient of $10^{-4}$ to $10^{-3} \mathrm{~m} \cdot \mathrm{s}^{-1}$ in fresh material and $10^{-6}$ to $10^{-5} \mathrm{~m} \cdot \mathrm{s}^{-1}$ in old samples.

7. Analysis of wastes incorporated into a dyke showed that the wastes from Upper Silesian Coal Basin changed their grain size distribution under the effect of environmental conditions more easily than did wastes from Lublin Coal Basin. Grain size structure of fresh wastes and wastes built in 10-years old dyke were similar. Wastes from USCB significantly changed their structure already after 2 years of natural weathering in an embankment. Analysed samples of mine wastes taken from the dyke's body were characterised by small coefficient of permeability and, in spite of 10-years period of natural weathering, were similar in that aspect to 5 and 7 -years old mine wastes taken from the heap.

\section{REFERENCES}

1. Badania właściwości fizyko-chemicznych skał karbońskich lokowanych na składowisku w Bogdance i ocena ich przydatności do rekultywacji. (Analyses of physical and chemical properties of carboniferous rocks located on coal mining dumps in Bogdanka and the assessment of their usefulness for restoration). Dokumentacja POMIAR-GIG Lublin, 2000. Red. J. Zawiślak. Lublin.

2. BoRYS M., FILIPOWICZ P., 2004a. Geotechnical parameters of mine wastes from The Lubelskie Coal Basin as a material for hydrotechnical embankments. J. Water Land Dev., 8: 163-170.

3. Borys M., FilipOWICZ P., 2004b. Possible utilization of mining wastes from the Lubelskie Coal Basin for hydrotechnical structures. Pol. J. Env. St., 13, 3: 146-148.

4. Borys M., FiliPOwiCZ P., 2005. Charakterystyka odpadów powęglowych i energetycznych dla ich zastosowania do budowy i modernizacji nasypów hydrotechnicznych. (Characteristics of mine and energetic wastes for their use to construct and modernize hydrotechnical embankments). Zesz. Probl. Post. Nauk Rol., 506: 77-84.

5. Borys M., Mosiej K., CZARtoryjski J., Filipowicz P., 2002. Wytyczne stosowania odpadów powęglowych z kopalni Bogdanka do budowy wałów przeciwpowodziowych i innych budowli hydrotechnicznych. (Recommendations for the use of coal mining wastes from Bogdanka Coal Mine to construct flood embankments and other hydrotechnical structures). Falenty, Wydaw. IMUZ: 68.

6. Cebulak S., KozŁowski K., 1980. Charakterystyka mineralogiczno-petrograficzno-chemiczna przywęglowych skał płonnych w profilach wiertniczych Cyców - 4, Łęczna - 4, Łęczna - 9 w Lubelskim Zagłębiu Węglowym. (Mineralogic, petrographic and chemical analysis of coal-accompanying rocks in drilling profiles Cyców - 4, Łęczna - 4, Łęczna - 9 in the Lublin Coal Basin). Pr. Nauk. U. Śl., 398: 47-52.

7. CiseK T., Kawalec B., Kopka Z., Soczawa A., 1982. Wpływ czasu składowania na właściwości nieprzepalonych odpadów kopalnianych. (The effect of storage time on the properties of unburnt mine wastes). Zesz. Nauk. P. Śl. Ser. Bud., 57: 25-45.

8. FILIPOWICZ P., BorYs M., 2006. Zakres zmienności wybranych parametrów geotechnicznych odpadów powęglowych wbudowanych w nasypy. (The range of variability of selected geotechnical parameters of mine wastes built in embankments). Woda. Środ. Obsz. Wiej., 6, 1 (16): 99-114.

9. FILIPOWICZ P., 2006. Wpływ czynników środowiskowych na parametry geotechniczne odpadów poweglowych $\mathrm{w}$ aspekcie ich zastosowania do budowy nasypów wodno-melioracyjnych. (The effect of environmental factors on geotechnical parameters of mine wastes in view of their use to construct water reclamation embankments). Falenty, Wydaw. IMUZ, rozpr. dokt.: 195.

10. GAZDA L., OleszCZyŃSKi B., POllo I., 1988. Charakterystyka mineralogiczno-chemiczna oraz analiza możliwości wykorzystania przeróbczych odpadów przywęglowych w kopalni w Bogdance. 
(Mineralogic and chemical characteristics and the analysis of the possible use of mine wastes in Bogdanka Coal Mine). Prz. Gór. 11-12: 16-18.

11. GRUCHOT A.T., 2001. Parametry wytrzymałościowe odpadów poweglowych w świetle badań laboratoryjnych prowadzonych $w$ aparaturze średniowymiarowej. (Strength parameters of mine wastes in view of laboratory analyses performed with the medium apparatus). Prz. Nauk. Wydz. Inż. Kształt. Środ., 20: 19-27.

12. KAWALEC B., 1976. Metody empiryczne ustalania wartości kątów tarcia wewnętrznego materiałów gruboziarnistych. (Empirical methods of estimating the apparent angle of internal friction in coarsegrained materials). Zesz. Nauk. P. Śl., Ser. Bud., 40: 33-41.

13. KozIELSKA-SROKA E., 1995. Wpływ wietrzenia na wytrzymałość na ścinanie odpadów poweglowych. (The effect of weathering on shear strength of mining wastes). Zesz. Nauk. AR Krak., 298, Ses. nauk., 45: 365-377.

14. KRZYK P., 2001. Wpływ czasu składowania na zmianę wybranych parametrów geotechnicznych nieprzepalonych odpadów powęglowych Kopalni Anna. (The effect of storage time on changes in some geotechnical parameters of unburnt mining wastes from Anna Coal Mine). Prz. Nauk. Wydz. Inż. Kształt. Środ., 20: 41-53.

15. KRZYK P., 2003. Wpływ czynników dezintegrujących na właściwości geotechniczne odpadów górnictwa wegla kamiennego. (The effect of disintegrating factors on geotechnical properties of coal mining wastes). Kraków, AR, rozpr. dokt.

16. PIECZYRAK J., 2004. Charakterystyka i przydatność techniczna odpadów górnictwa węgla kamiennego. Zastosowanie odpadów przemysłowych i geosyntetyków w budownictwie ziemnym. (Characteristics and technical usefulness of the coal mining wastes. The use of industrial wastes and geosynthetics in ground engineering). Kraków, Wydaw. AR: 177-183.

17. PN-88/B-04481: Grunty budowlane. Badanie próbek gruntu. (Engineering grounds. Analysis of earth samples).

18. SKARŻYŃSKA K.M., 1997. Odpady powęglowe i ich zastosowanie w inżynierii lądowej i wodnej. (Mining wastes and their use in civil and water engineering). Kraków, Wydaw. AR: 199.

19. SKARŻYŃSKA K.M., BURDA H., 1988. Analiza kontroli jakości zagęszczania nasypów wykonanych $\mathrm{z}$ nieprzepalonych odpadów węgla kamiennego. (Analysis of the quality control of compaction in embankments made of unburnt coal mining wastes) Gosp. Wod., 10: 231-233.

20. SkarŻyŃSKa K.M., Burda H., KozielSKA-Sroka E., MichalSki P., 1987. Laboratory and site investigations on weathering of coal mining wastes as a fill material in earth structures. W: Reclamation, treatment and utilization of coal mining wastes. Ed. A.K.M. Rainbow. Amsterdam: Elsevier Sci. Publ. B.V.: 179-195.

21. StochlaK J., SzCZerbiŃSKi J., 1981. Właściwości chemiczne i fizyczne skał przywęglowych i odpadów przeróbczych Lubelskiego Zagłębia Węglowego. (Chemical and physical properties of coalaccompanying rocks and mining wastes from the Lublin Coal Basin). Prz. Gór., 5: 241-253.

22. Surowce mineralne środkowowschodniej Polski, 1984. (Natural resources of mid-eastern Poland). Pr. zbior. Red. S. Kozłowski. Warszawa, Wydaw. Geol.

23. TwARDOWSKA I., 1981. Mechanizm i dynamika ługowania odpadów karbońskich na zwałowiskach. (The mechanism and dynamics of leaching carbonaceous wastes in dumps. Wrocław, Ossolineum. 


\section{STRESZCZENIE}

\section{Analiza porównawcza parametrów geotechnicznych odpadów powęglowych z Lubelskiego Zagłębia Węglowego i odpadów z innych zagłębi}

Słowa kluczowe: nasypy ziemne, odpady poweglowe, skład granulometryczny, właściwości mechaniczne, wytrzymatość na ścinanie

W Polsce funkcjonuje obecnie 40 kopalń węgla kamiennego, z czego jedna „Bogdanka” - jest położona w Lubelskim Zagłębiu Węglowym, a pozostałe są zlokalizowane w regionie Śląska i Małopolski. Górnictwo węglowe jest źródłem dużych ilości materiałów odpadowych. Tylko w Lubelskim Zagłębiu Węglowym średnio rocznie produkuje się ponad $2 \mathrm{mln} \mathrm{Mg}$ odpadów powęglowych, z czego około 65\% składowane jest na hałdzie. Pozostałą część wykorzystuje się do rekultywacji wyrobisk odkrywkowych po kruszywach, budowy i remontu dróg lokalnych oraz produkcji materiałów budowlanych. Wydaje się, że znaczna część tych odpadów mogłaby być wykorzystana do budowy i modernizacji takich nasypów wodno-melioracyjnych, jak wały przeciwpowodziowe czy ogroblowania kanałów i zbiorników wodnych. Zastosowanie odpadów jako gruntu budowlanego wymaga znajomości ich parametrów geotechnicznych. Cechą charakterystyczną tych odpadów jest ich stopniowe wietrzenie, mające między innymi wpływ na parametry geotechniczne, zależne w dużym stopniu od składu petrograficznego i mineralnego.

W niniejszym artykule omówiono badania parametrów geotechnicznych odpadów powęglowych z Lubelskiego Zagłębia Węglowego, pochodzących z hałdy kopalni węgla kamiennego „Bogdanka”, o różnym okresie ich składowania, oraz prób pobranych po 10 latach eksploatacji z grobli międzystawowej wykonanej na przełomie lat 1993 i 1994 z odpadów powęglowych z tej kopalni. Szczegółowo zostały omówione wybrane właściwości geotechniczne tych odpadów, m.in.: uziarnienie, wilgotność naturalna, wilgotność optymalna, maksymalna gęstość objętościowa szkieletu gruntowego, wytrzymałość na ścinanie, współczynnik filtracji. Uzyskane wyniki badań własnych porównano z wynikami prezentowanymi w literaturze, dotyczącymi odpadów powęglowych pochodzących z Górnośląskiego Zagłębia Węglowego, a także z innych zagłębi na terenie Europy.

Przeprowadzone badania wykazały m.in., że odpady powęglowe powstające w Lubelskim Zagłębiu Węglowym różnią się zasadniczo pod względem uziarnienia od odpadów pochodzących z Górnośląskiego Zagłębia Węglowego oraz że przebieg procesu wietrzenia dla odpadów z LZW i GZW był różny.

Reviewers:

Prof. Andrzej Dragowski

Prof. Eugeniusz Zawisza 